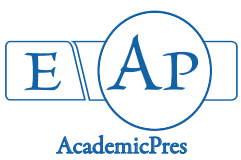

Panfilova A (2021)

Notulae Scientia Biologicae

Volume 13, Issue 4, Article number 11035

DOI: $10.15835 / \mathrm{nsb} 13411035$

Research Article

\title{
Influence of stubble biodestructor on soil microbiological activity and grain yield of winter wheat (Triticum aestivum L.)
}

\author{
Antonina PANFILOVA
}

Mykolayiv National Agrarian University, Faculty of Agricultural Technologies, George Gongadze St., 9, Mykolayiv, 54020 ,

Ukraine; panfilovaantonina@ukr.net

\begin{abstract}
The aim of the work was to improve soil fertility and increase the yield of winter wheat using the stubble biodestructor by activating the microbiological activity of the soil. The experimental studies were on the research field of Mykolayiv National Agrarian University (Ukraine). After harvesting the precursor cultures of spring barley and peas the post-harvest residues of these crops were treated with a stubble biodestructor. After treatment of crop residues of spring barley and pea by the stubble biodestructor in the soil layer of 0 up to 20 $\mathrm{cm}$ the quantity of cellulose-destructive microorganisms increased by $27 \cdot 9 \cdot 10^{5}$ up to $36.0 \cdot 10^{5} \mathrm{cfu} / \mathrm{g}$ of soil depending on the predecessor culture and the degree of degradation of these residues increased by 31.4 up to $45.1 \%$. The number of nitrogen fixators in the $0-10 \mathrm{~cm}$ soil layer grew under the action of treatment of crop residues of spring barley and peas by stubble biodestructor on 13.4 up to $14.1 \cdot 10^{6} \mathrm{cfu} / \mathrm{g}$ of soilor 30.3 up to $35.0 \%$. At the same time, a somewhat large number of bacteria in the soil was determined by the processing of post-harvest residues of peas, which was due to the biological characteristics of this legume culture. The average for years of researches at cultivating of winter wheat after spring barley using the stubble biodestructor the grain yield increased by $0.45 \mathrm{t} \mathrm{ha}^{-1}$, or $20.9 \%$, and after pea it increased by $0.67 \mathrm{t} \mathrm{ha}^{-1}$ or $18.8 \%$ compared to the treatment variant of stubble just with water.
\end{abstract}

Keywords: after-harvest residues of pea and spring barley; cellulose-destructive microorganisms; stubble biodestructor; the destruction rate; the grain yield of winter wheat

\section{Introduction}

The problem of preserving and improving soil fertility without disturbing the natural equability of processes in agroecosystems is extremely relevant for agricultural production in Ukraine (Nilova et al., 2017).

One of the most important resources in increasing crop yields and improving soil fertility are organic fertilizers, which have traditionally satisfied 30 to $50 \%$ of plant nutritional needs. Organic substances containing macro-and microelements enrich the soil with humus, microflora and improve its physical and chemical properties. One of the main types of organic fertilizers at the present stage of management is the straw of cereal crops, which enriches the soil with organic matter, enhances the life of the microflora and the intensity of its respiration, improves the nutrient regime of the soil (Sendetsky, 2018).

Over the past 20-25 years due to the catastrophic reduction of livestock, the application of organic fertilizers in Ukraine decreased from $9.6 \mathrm{tha}^{-1}$ in 1990 up to $1.0 \mathrm{t} \mathrm{ha}^{-1}$ in 2016-2017 (Balayev and Pikovskaya,

Received: 22 Jul 2021. Received in revised form: 09 Nov 2021. Accepted: 12 Nov 2021. Published online: 16 Nov 2021.

From Volume 13, Issue 1, 2021, Notulae Scientia Biologicae journal uses article numbers in place of the traditional method of continuous pagination through the volume. The journal will continue to appear quarterly, as before, with four annual numbers. 
2016). According to the state service of statistics of Ukraine in 1990 it was made of 8.6 tons of organic fertilizers per 1 hectare, and in 2018 it was made only $0.5 \mathrm{t} \mathrm{ha}^{-1}$, the amount of mineral fertilizers in the amount of NPK accordingly decreased from $141 \mathrm{~kg} \mathrm{ha}^{-1}$ up to $112 \mathrm{~kg} \mathrm{ha}^{-1}$, including such little difference between the latest figures (25.9\%) was covered mainly by the application of nitrogen fertilizers. Thus, from $141 \mathrm{~kg} \mathrm{ha}^{-1}$ of mineral fertilizers, which were introduced in 1990, the amount of nitrogen was $59 \mathrm{~kg} \mathrm{ha}^{-1}$, the amount of phosphorus was $43 \mathrm{~kg} \mathrm{ha}^{-1}$ and the amount of potassium was $39 \mathrm{~kg} \mathrm{ha}^{-1}$, then in $2018 \mathrm{NPK}$ accounted for 79; 16 and $17 \mathrm{~kg}$ $\mathrm{ha}^{-1}$, respectively (in total $112 \mathrm{~kg} \mathrm{ha}^{-1}$ ). In such a situation, there was some deficit in the amount of applied fertilizer to the nutrient removal with crop harvest, moreover, and thus it was broken the optimal ratio of $\mathrm{N}: \mathrm{P}: \mathrm{K}$. The special concern causes a significant decrease in the use of organic fertilizers, the amount added to the level of 1990 and it is amounted in 2018 near 6\%.

A substantial portion of nutrients is alienated with the harvest (his trade part) and without their compensation, increases the deficiency of macro - and micronutrients. Analysing modern approaches to management, from the point of view of changes in soil fertility, the authors note that in fact there is an active depletion of soil cover, the processes of degradation are enhanced, the proportion of soils with high and very high humus content decreases while their growth is low and medium (Veremeenko and Semenko, 2019).

In addition, about $70 \%$ of the total volume of mineral fertilizers, as we have already noted, is nitrogen. This is a regularity, as for most types of soil differences, including in the zone of the southern Steppe of Ukraine, the first minimum is nitrogen nutrition of plants. However, as determined by our long-term studies, it is most appropriate to meet part of their nitrogen needs by including legumes into the selection in the crop rotation which are able to accumulate biological nitrogen, as it does not pollute the soil, it is not lost, and $100 \%$ of it is used by plants.

Besides, legumes are capable of dissolving of hard fixed phosphates and transform them into available forms (Gamajunova, 2017). At the same time, it is also known that legumes accelerate the decomposition of straw and stubble residues, if after their incorporation into the soil and next harvesting of the cereal crops it will be sown a grass mix with a legume component.

Therefore, annually reducing of the volume of organic fertilizers in Ukraine is deteriorating soil fertility, it becomes its degradation due to the lack of traditional resources of organic raw materials (half-degraded manure) to ensure deficit-free balance of humus. This necessitates the attraction of additional reserves of local organic raw materials. One of the significant levers in increasing soil fertility is the use of straw and other plant residues as organic fertilizer (Gamajunova, 2017; Hossain et al., 2017). Namely, organic matter plays a decisive role in the reproduction of soil fertility. It is the basis and coordinator of soil formation processes and an important source of nutrients for plants. An important reserve of organic matter in the soil (in the absence of manure and other known types of organic fertilizers) is agricultural by-products (straw, tops, stems, root residues, and the like) (Nilova, 2017).

The return of plant substances to the soil should be given utmost importance, as they are the main source of organic carbon for soil biota and subsequent crop rotation. In this process, one of the strategic directions of the development of modern agriculture is the use of biological drugs, which allows to restore natural resources. An important part of such means belongs to products of microbial decomposers. In the case of their application, the natural process of decomposition of fiber by living organisms is accompanied by an increase in the number of useful soil microorganisms, activation of their vital activity and suppression of pathogenic microflora. Along with the improvement of soil fertility it occurs its recovery (Sendetsky, 2018).

In recent years in Ukraine, considering the experience of foreign firms, the decomposition of straw and plant residues accelerate through technologies, which (depending on soil and climatic conditions farming systems, crop rotations, tillage) provides the general requirement such as the colonization of the residues of selection, most useful and viable and resistant to adverse conditions, particularly to high temperatures and UV radiation, with microorganisms, fungi and bacteria. For such purposes, plant residues are treated with biologically active substances such as destructors (Sendetsky, 2019). Due to destructors, the rate of soil degradation slows down, the mass of soil microflora increases up to 3-5 tha ${ }^{-1}$ and thus the biological activity of 
the soil is maintained, it heals. Unlike traditional technology (burning or plowing of plant residues) the biodestructor accelerates the decomposition of plant residues without destroying valuable organic matter; it improves soil fertility, it increases crop productivity by 10 up to $30 \%$; it prevents the development of pathogens and pests (Gamajunova et al., 2011).

Today, the biological condition of many soils in the country should be recognized as subject to degradation. It is proved by studies that microorganisms play an exceptional role in soil processes, as under the influence of biological factors, the basic properties of soils are created which distinguish them from rock. In each separate layer of the arable horizon microorganisms are placed unevenly. In addition, there is a general tendency to a gradual decrease in the number of microorganisms in the deeper layers of the soil (Lupwayi et al., 2012; Molina-Montenegro et al., 2016; Hydbom et al., 2017).

Without a systematic income of organic matter and imbalanced use of fertilizers, ignoring of reasonable selection of crops in crop rotations, significant reduction the cultivation of leguminous crops, straw burning, etching the soils it is activated dehumification processes. It is significantly depleted composition of the soil biocenosi, it is observed minimizing and even loss of individual species of beneficial organisms. Part of agricultural lands turned into the weeds of pathogens. The amplitude of such phenomena causes serious concern and the need for urgent adoption both at the state level and directly in the farms, measures to optimize the state of agrocenosis in general and soil-forming processes in particular (Volkogon, 2011).

An important indicator of the biological activity of the soil is the intensity of decomposition of organic substances contained in the soil and enter it with organic fertilizers. The application of post-harvest residues stimulates the growth and development of soil microbiota, cellulose-destroying, nitrogen-fixing and other microorganisms which improve soil fertility, and, as a result, it increases the yield levels of the following crops in the crop rotation. One of such crops is winter wheat, the yield of which depends primarily on the predecessor in crop rotation, variety, fertilizer system, water and temperature during the growing season (Panfilova et al., 2020).

Today, to increase grain yield, a large number of drugs are used, including growth-regulatory and biological drugs (Panfilova and Mohylnytska, 2019; Panfilova et al., 2020). That is why, one of the objectives of our research was to increase the productivity of winter wheat through the use of treatment of post-harvest residues of precursor crops (spring barley and peas) by the stubble biodestructor, which reduces the material and energy costs of growing crops.

\section{Materials and Methods}

\section{Location of experience and biological material}

Experimental researches were carried out during 2011-2016 on the experimental field of the Mykolayiv National Agrarian University, Ukraine. The object of research was 'Kolchuga' winter wheat variety. The technology of its cultivation, except for the studied factors, was generally accepted to the existing zonal recommendations for the southern steppe of Ukraine.

\section{Experimental procedures}

The scheme of experience included the following variants: Factor A as culture predecessor: 1. Spring barley; 2. Pea; Factor B as the treatment of crop residues: 1 . Control as water treatment; 2 . Treatment by the stubble biodestructor.

After harvesting of the predecessors of spring barley and peas post-harvest residues of these crops were treated with the stubble biodestructor (private enterprise "BTU-center", Ukraine) at a dose of 2 liters of a biological product with the addition of $3.0 \mathrm{~kg}$ of ammonium nitrate the working solution was 300 liters per 1 ha, and then it was conducted disking of residues with heavy disc harrow BDT-7 at a depth of 10-12 cm. Winter wheat was sown according to the experiment scheme in the first decade of October. 
The preparation of the stubble biodestructor consists of bacteria-antagonists of pathogenic fungi to plants and bacteria, soil bacteria phosphate-mobilizers, natural endophytic and soil bacteria nitrogen-fixing bacteria, lactic acid bacteria, producers of pulp, biofungicides, phytohormones, vitamins, amino acids, macro and microelements.

To determine the total bacterization, the number of cellulose-destructing microorganisms it was twice selected soils amplest before treatment of crop residues with the biodestructor and three months after, when it happened their partial mineralization. Research and accounting were carried out according to generally accepted methods and the state standard. In the soil samples were determined: the total number of microorganisms-sowing on peptone-glucose agar from the soil extract and cultivation at $\mathrm{T} 30^{\circ} \mathrm{C}$ for 4 days; nitrogen fixers- sowing on nitrogen-free medium and cultivation at $\mathrm{T} 30^{\circ} \mathrm{C}$ for 4 days; cellulose-destroying microorganisms - on Hutchinson and Clayton medium with ashless paper filter for 10 days; fungi sowing on wort-agar medium and cultivation at $\mathrm{T} 30^{\circ} \mathrm{C}$ for 7 days.

In the process of research, it was used the method of state variety testing of agricultural crops (Volkodav, 2001). The yield of winter wheat grain was determined by the method of continuous harvesting from the entire accounting area (combine-harvester Sampo-130).

Statistical analysis of experimental data was performed using the computer program Agrostat.

\section{Results and Discussion}

Bacteria are the most common and important components of the Earth's biota. They catalyse the processes of unique and irreplaceable transformations in the biochemical cycles of the biosphere, they create important components of the atmosphere, and represent a large part of the genetic diversity of life. They produce important compounds which are a source of nutrients and they are used by all components of the food chain (Salmonová and Bunešová, 2017). Assessment of the soil ecosystem state in terms of the use of biological preparations requires clarification of the microbial cenosis state as one of the sensitive diagnostic criteria of soil fertility.

The number of soil microflora is subject to significant fluctuations depending on the type of soil, moisture supply of the growing season, the method of basic tillage, crop selection and the order of their alternation in crop rotation. The results of research have shown that any crop created a characteristic microbial group in the soil (Wang et al., 2017; Kôlli, 2018). In our studies, a comparative analysis of the quantitative characteristics of the microbial grouping of soil samples before treatment of post-harvest residues with stubble biodestructor showed that the number of bacteria and microscopic fungi in the soil samples varied depending on the precursor culture (Table 1).

Table 1. Microbiological activity of the soil before treatment of post-harvest residues with stubble biodestructor, PCs./1 g of soil (average for 2011-2015)

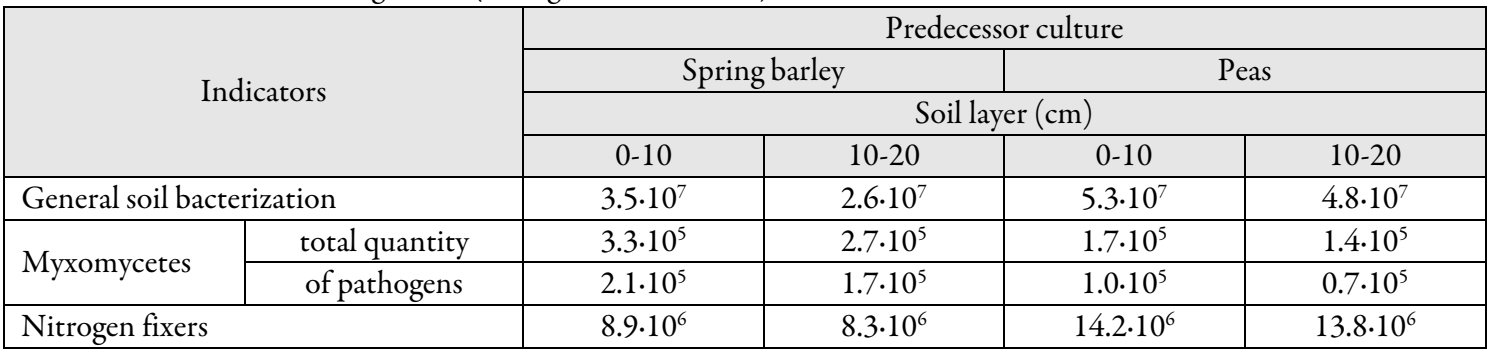

The results of microbiological analysis of the soil before processing post - harvest residues with stubble biodestructor indicated that the total number of bacteria in the studied soil layers was determined to be slightly 
lower after growing spring barley and in the $0-10 \mathrm{~cm}$ soil layer it was $3.5 \cdot 10^{7} \mathrm{PCs} . / \mathrm{g}$ of soil, and in a layer of $10-20 \mathrm{~cm}$ it was $2.6 \cdot 10^{7}$ PCs. $/ 1 \mathrm{~g}$ of soil.

After harvesting peas in a soil layer of $0-10 \mathrm{~cm}$, there were $5.3 \cdot 10^{7} \mathrm{PCs} . / 1 \mathrm{~g}$ of soil bacteria, and in a layer of $10-20 \mathrm{~cm}$ there were $4.8 \cdot 10^{7} \mathrm{PCs} . / 1 \mathrm{~g}$ of soil, which respectively by $1.8 \cdot 10^{7}$ and $2.2 \cdot 10^{7} \mathrm{PCs} . / 1 \mathrm{~g}$ of soil, was more compared to samples after growing spring barley.

The total number of myxomycetes, on the contrary, was more determined in the soil after growing spring barley $-2.7 \cdot 10^{5}-3.3 \cdot 10^{5}$ PCs. $/ 1 \mathrm{~g}$ of soil, depending on the layer under study. At the same time, pathogens accounted for $62.9-63.3 \%$.

Treatment of post-harvest residues with a biodestructor, on average for precursor crops, led to an increase in the total number of bacteria in the soil on the $7.3 \cdot 10^{7}-7.5 \cdot 10^{7}$ PCs. $/ 1 \mathrm{~g}$ of soil or $63.0-66.4 \%$, depending on the studied layer (Table 2).

Table 2. Influence of stubble biodestructor on soil microbiological activity, PCs./ $1 \mathrm{~g}$ of soil (three months after processing, average for 2011-2015)

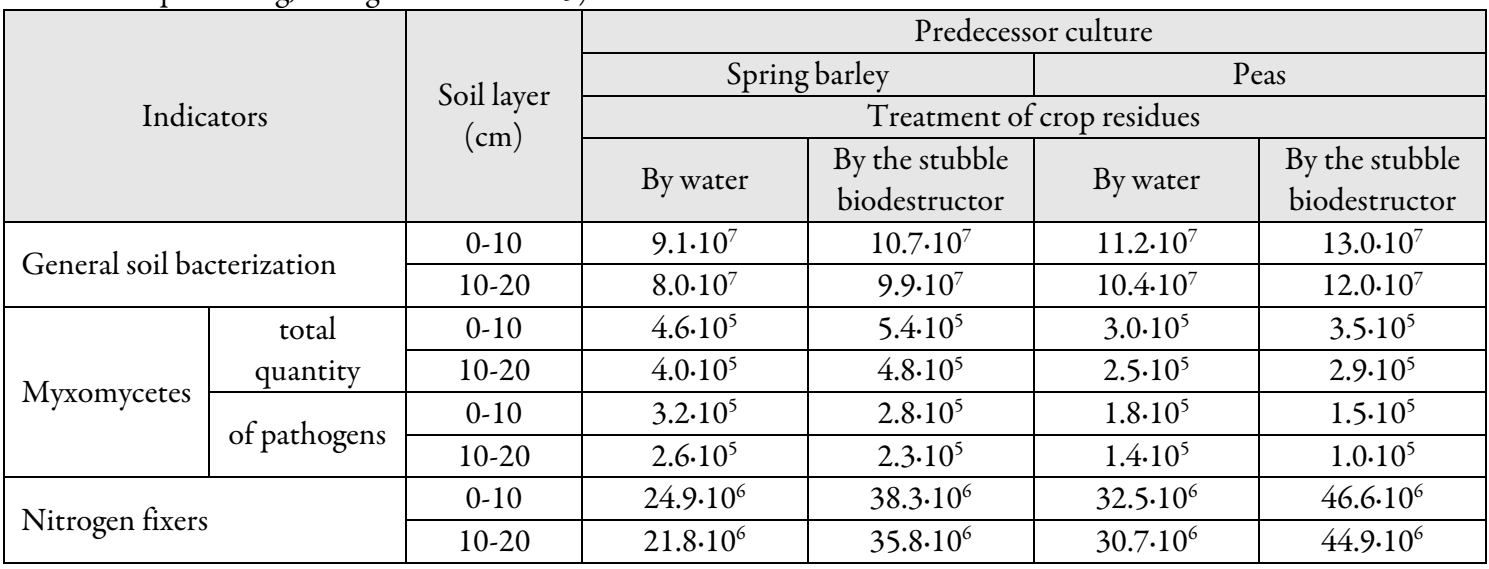

At the same time, it should be noted that in areas without the use of biopreparations, and when treating crop residues with water, the total amount of bacterial microflora also increased slightly compared to the initial amount, but this occurred to a lesser extent $-9.2 \cdot 10^{7}-10.2 \cdot 10^{7}$ PCs. $/ 1 \mathrm{~g}$ of soil, i.e. on $5.5 \cdot 10^{7}-5.8 \cdot 10^{7}$ PCs. $/ 1 \mathrm{~g}$ of soil or by $56.9-59.8 \%$ depending on the soil layer.

The number of micromycetes under the action of stubble biodestructor also increased slightly compared to their determination before processing post-harvest residues - on average, over the years of research and for predecessor crops by $44.4 \%$ in the soil layer $0-10 \mathrm{~cm}$, and by $46.2 \%$ in the soil layer $10-20 \mathrm{~cm}$. At the same time, when treating the remains only with water (under natural decomposition conditions), the number of microscopic fungi in the soil layer $0-10 \mathrm{~cm}$ increased by $34.2 \%$, and $10-20 \mathrm{~cm}$ it increased by $36.4 \%$. Studies also determined that the use of stubble biodestructor led to a certain decrease in the proportion of pathogenic fungi in the soil, regardless of the precursor culture.

It should be noted that the studied factors also influenced on the quantitative characteristics of pathogenic microscopic fungi. So, on average, over the years of research, regardless of the treatment of postharvest residues, slightly more pathogenic fungi were identified after embedding the remains of spring barley into the soil $-2.8 \cdot 10^{5}-3.2 \cdot 10^{5}$ and $2.3 \cdot 10^{5}-2.6 \cdot 10^{5}$ PCs. $/ 1 \mathrm{~g}$ of soil depending on the soil layer. At the same time, the use of a biodestructor reduced this indicator by $11.5-12.5 \%$ compared to the variant of treating postcrop residues with water. An increase in the number of myxomycetes in the soil may be evidence of an increase in its overall toxicity, which in turn may be a consequence of a violation of the alternation of agricultural crops in crop rotation, the introduction of an unjustified amount of mineral fertilizers, etc.

The cultivation of legumes, in particular peas, contributed to a decrease in the amount of pathogenic fungal microflora compared to the variants for growing spring barley, which can be explained by the biological 
features of peas, based on the ability of plants to symbiotic activity with soil microorganisms, natural fixation of molecular nitrogen, and as a result, the natural enrichment of the soil for plant nutrition elements and generally improving its fertility.

The issue of optimal supply of nitrogen to agrocenoses is closely related to the microbiological fixation of this element from the air. Intensification of the nitrogen fixation process in agrocenoses becomes possible if legumes are grown and nitrogen-fixing microorganisms are used, the functioning of which is an important factor in increasing soil fertility. In addition, nitrogen fixation is the only way to provide plants with biological nitrogen that does not disrupt the ecological balance in the environment.

In our studies, the use of post-harvest treatment of spring barley and pea residues with stubble biodestructor contributed to an increase in the amount of nitrogen fixers in the soil. So, in a 0-10 cm layer of soil, there were variants without the use of a biological product of nitrogen fixers $24.9 \cdot 10^{6}-32.5 \cdot 10^{6} \mathrm{PCs} . / \mathrm{g}$ of soil, and in a layer of $10-20 \mathrm{~cm}$ there were $21.8 \cdot 10^{6}-30.7 \cdot 10^{6} \mathrm{PCs} . / \mathrm{g}$ of soil, which was respectively on the $13.4 \cdot 10^{6}-14.1 \cdot 10^{6}$ and $14.0 \cdot 10^{6}-14.2 \cdot 10^{6}$ PCs. $/ 1 \mathrm{~g}$ of soil or $30.3-35.0$ and $31.6-39.1 \%$ less compared to the variants for using stubble biodestructor.

It should be noted that the use of peas as a precursor crop provides a slightly larger amount of nitrogen fixers compared to spring barley - in the soil layer $0-10 \mathrm{~cm}$ per day $7.6-8.3 \cdot 10^{6} \mathrm{PCs} . / \mathrm{g}$ of soil or $17.8-23.4 \%$, and in a layer of $10-20 \mathrm{~cm}-$ on 8.9 it is $9.1 \cdot 10^{6}$ PCs. $/ 1 \mathrm{~g}$ of soil or $20.3-29.0 \%$, depending on the variant of processing post-harvest residues.

Dispersion analysis of experimental data on the amount of nitrogen fixers in the soil layer $0-20 \mathrm{~cm}$ revealed a significant influence of Factor B such as treatment of post-crop residues with a stubble biodestructor $(72.43 \%)$, and the action of the precursor culture was less effective (27.32\%), due to the interaction of these factors $(0.02 \%)$.

The cellulolytic activity of microbial cenosis and the intensity of respiration are one of the main integrating indicators characterizing the activity and the number of vital activities of soil biota (Korsun et al., 2018; Markovskaya, 2018). Cellulose is the most abundant organic polysaccharide on the Earth's surface, and cellulolytic microorganisms in turn play a key role in maintaining of the global carbon cycle. The study determined that most cellulolytic bacteria belong to the Actinobacteria (aerobic bacteria) and Firmicutes (anaerobic bacteria), whereas all the kingdom of filamentous fungi include Ascomycetes, Basidiomycetes, Deuteromycetes (aerobic fungi) and Chytridiomycetes (anaerobic fungi) and most of the groups and types cellulolytic fungi. Our research through a comparative analysis of the quantitative characteristics of microbial groups of soil samples before processing of crop residues with the stubble biodestructor determined that the number cellulolytic bacteria in soil samples depended on culture-predecessor (Table 3).

Table 3. Effect of the stubble biodestructor on the number of cellulose-destroying microorganisms in the soil layer 0-20 cm, PCs./1 g of soil (average for 2011-2015 yrs)

\begin{tabular}{|l|c|c|c|}
\hline \multirow{2}{*}{ Culture predecessor } & \multirow{2}{*}{$\begin{array}{c}\text { Before treatment } \\
\text { of crop residues } \\
\text { (after harvesting } \\
\text { predecessor) }\end{array}$} & \multicolumn{2}{|c|}{$\begin{array}{c}\text { After processing of post-harvest residues } \\
\text { with the stubble biodestructor }\end{array}$} \\
\cline { 3 - 4 } & $10.9 \cdot 10^{5}$ & $\begin{array}{c}\text { Treatment } \\
\text { with water }\end{array}$ & $\begin{array}{c}\text { Treatment with the } \\
\text { biopreparation }\end{array}$ \\
\hline Spring barley & $14.5 \cdot 10^{5}$ & $20.5 \cdot 10^{5}$ & $38.8 \cdot 10^{5}$ \\
\hline Peas & $0.896-4.245$ & $29.8 \cdot 10^{5}$ & $50.5 \cdot 10^{5}$ \\
\hline $\mathrm{LSD}_{0.5}$ & \multicolumn{2}{|c|}{ factor A: $0.745-1.952$; factor B: $0.439-1.785$} \\
\hline
\end{tabular}

The results of microbiological analysis of the soil sampled before processing of crop residues with the stubble biodestructor, showed that cellulolytic bacteria in the investigated soil layer was defined a little less after harvesting spring barley and at the average for the study years was $10.9 \cdot 10^{5} \mathrm{PCs} . / \mathrm{g}$ of soil.

After harvesting the peas in the soil there were $14.5 \cdot 10^{5}$ PCs./ $1 \mathrm{~g}$ of soil bacteria, respectively to $3.6 \cdot 10^{5}$ PCs. $/ 1 \mathrm{~g}$ of soil or by $24.8 \%$ in comparison with spring barley. 
Treatment of crop residues with the biodestructor, the average for years of research led to the increase in the number of cellulolytic microorganisms in the soil by $27.9 \cdot 10^{5}$ up to $36.0 \cdot 10^{5} \mathrm{PCs}$. $/ 1 \mathrm{~g}$ of soil depending on the predecessor culture. It should be noted that on the plots without the use of a biological product, that is, processing of post-harvest residue with water, the total amount of bacterial flora was also somewhat increased compared to the initial number of them, but it happened to a lesser extent, by $9.6 \cdot 10^{5}$ up to $15.3 \cdot 10^{5} \mathrm{PCs} . / 1 \mathrm{~g}$ of soil or 46.8 up to $51.3 \%$ depending on the culture of its predecessor.

An important indicator of the soil biological activity is the intensity of decomposition of organic substances contained in the soil and replenish it by applying organic fertilizers, plant and animal residues and other substances. The main source of energy for soil biota is fibre. Therefore, it is necessary to maintain the activity of useful soil microflora by treating it and plant residues with biological preparations, an example of which is the stubble biodestructor.

The decomposition of cellulose is significantly influenced by hydrothermal conditions, soil structure, chemical composition of organic substances and other factors. The post-harvest period in the southern Steppe of Ukraine is characterized by high air temperatures. Thus, the average daily temperature in July and August in the years of our research was at the level of $+22.7 \ldots+26.6^{\circ} \mathrm{C}$ and $+22.5 \ldots+24.3^{\circ} \mathrm{C}$, respectively, in September $+14.8 \ldots+19.2^{\circ} \mathrm{C}$ and only in October there is a significant decrease to $+9.0 \ldots+14.2^{\circ} \mathrm{C}$. However, rainfall was usually negligible during this period. This course of weather conditions and the soil condition are not always favourable for the effective activity of microbial preparation such as the stubble biodestructor. However, its use significantly accelerated the destruction of crop residues in comparison with the variants for processing plant residues only with water (Figure 1).

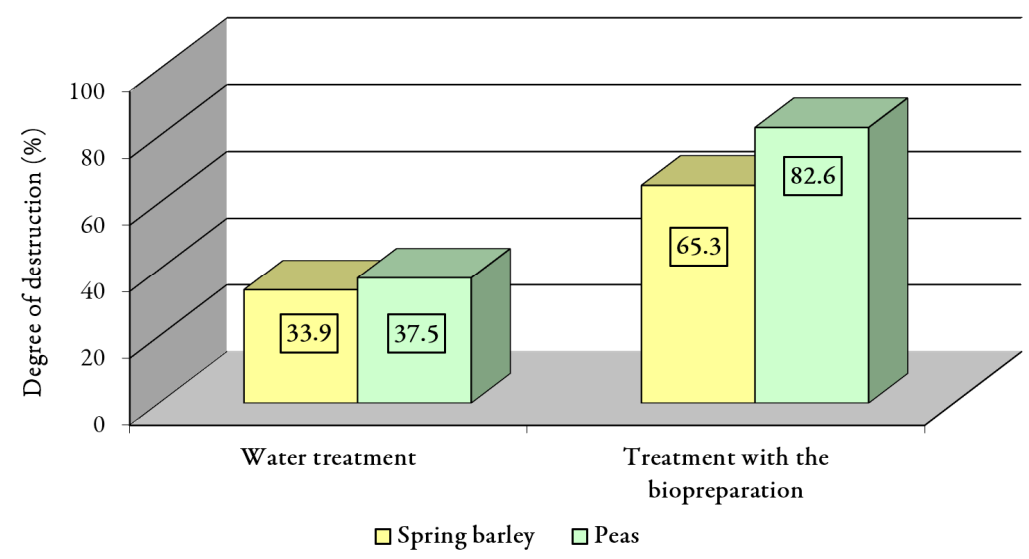

Figure 1. Degree of destruction of crop residues 90 days after treatment with the stubble biodestructor, $\%$ (average for 2011-2015 yrs)

LSD $_{0.5}$ : Factor A (culture predecessor): 1.739-3.015. Factor B (the treatment of crop residues): 0.661-1.393

The most intense decomposition of plant residues in 90 days after treatment with biopreparation as $82.6 \%$ was determined in soil after harvesting of pea as a cultural predecessor, which was by $54.6 \%$ more compared to the control for processing of the residues with water. Very effective action of the stubble biodestructor was evident on the spring barley, where it was decomposed $65.3 \%$ of post-harvest residues, whereas the treatment with only water provided the degree of decomposition of plant residues at the level of $33.9 \%$.

The rate of destruction of post-harvest residues significantly depends on the earned crop residues. Thus, on average, over the years of research and treatment variants, after 90 days in soil samples taken after growing peas, the organic matter content was $60.1 \%$, which was by 17.5 relative percent more compared to the sealing of residues of spring barley. 
At the present stage of agricultural development, the direction of research on soil microbiological processes, where soil microorganisms are an important component of the biological cycle of substances, is becoming relevant. The study of soil biological activity allows scientists to better understand and identify patterns in the processes of organic matter transformation, taking into account the anthropogenic impact on the soil and its properties. Increasing soil fertility in the field of grain production depends not only on the introduction of organo-mineral components and the quality of cultivation, but also on compliance with the rules for selecting precursors and processing their post-crop residues with biodestructors (Gamajunova et al., 2021). As someone knows, the plant is in a harmonious relationship with the active complex of soil microorganisms, which are a trophic intermediary between the root system and the soil. Due to this, the plant is able to more fully realize the genetic potential of yield. In our studies, the improvement of the microbiological state of the soil after processing the post-harvest remains of precursor crops in the crop rotation contributed to an increase in the yield of winter wheat grain. Our studies found that in some years of cultivation, and on average for five years, the yield of winter wheat grain was formed higher by placing it on peas (Figure 2). After spring barley, it was 1.19 up to $1.41 \mathrm{tha}^{-1}$ or 39.6 up to $41.2 \%$ lower depending on the application of the stubble biodestructor.

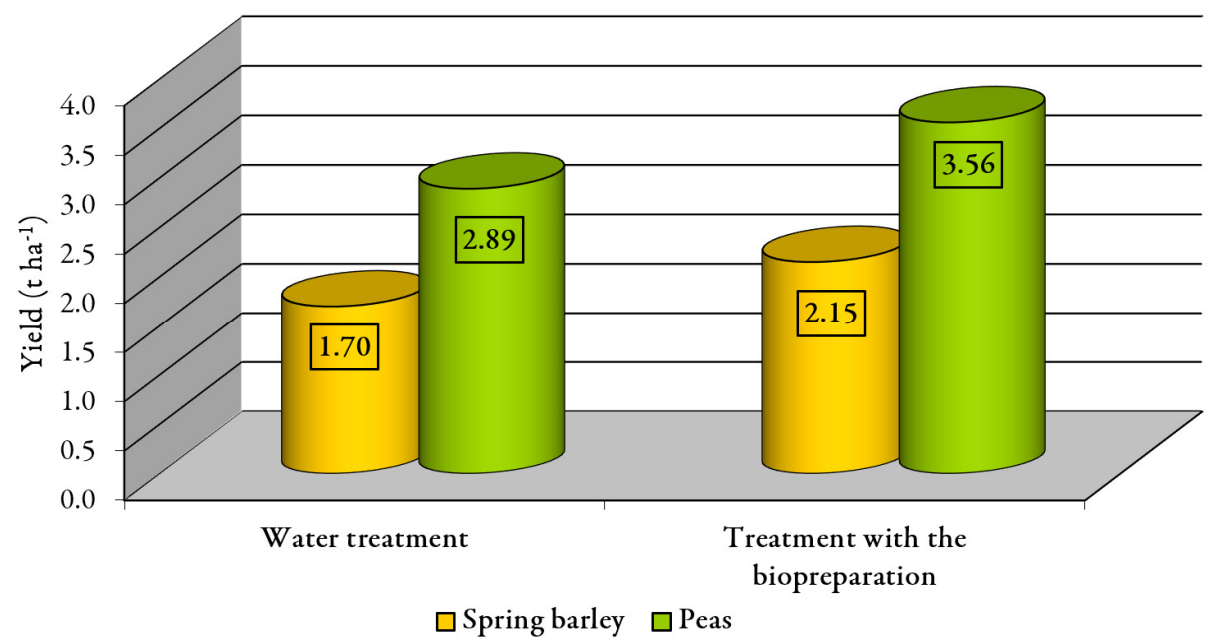

Figure 2. Grain yield of winter wheat depending on the treatment of predecessor crop residues with the stubble biodestructor, $\mathrm{t} \mathrm{ha}^{-1}$ (average for 2012-2016 yrs)

$\mathrm{LSD}_{0.5}:$ Factor A (culture predecessor): 0.08-0.016. Factor B (the treatment of crop residues): $0.07-0.14$

The yield of winter wheat grain naturally grew on the background of processing of post-harvest residues of its predecessors with biopreparation. Thus, on average during the years of the study, for the cultivation of winter wheat after spring barley and the application of the stubble biodestructor the grain yield increased by $0.45 \mathrm{t} \mathrm{ha}^{-1}$, or $20.9 \%$, and after pea it increased by $0.67 \mathrm{tha}^{-1}$ and $18.8 \%$ compared with stubble treatment with only water.

\section{Conclusions}

After treatment of crop residues of spring barley and peas by the stubble biodestructor with the addition of ammonium nitrate in the amount of $3.0 \mathrm{~kg} \mathrm{ha}^{-1}$, the microbiological activity of the soil is activated, the degree of destruction of post-harvest residues increases and the level of yield of winter wheat grain increases. Thus, treatment of post-harvest residues with a biodestructor, on average for precursor crops, led to an increase in the total number of bacteria in the soil on the $7.3 \cdot 10^{7}-7.5 \cdot 10^{7}$ PCs./ $1 \mathrm{~g}$ of soil or $63.0-66.4 \%$, depending on the 
studied layer. On average, on the years of researches in the soil layer of 0 up to $20 \mathrm{~cm}$ the quantity of cellulosedestructing microorganisms increased by $27.9 \cdot 10^{5}$ up to $36.0 \cdot 10^{5}$ PCs. $/ 1 \mathrm{~g}$ of soil depending on the predecessor culture and the degree of degradation of these residues increased by 31.4 up to $45.1 \%$. At the same time, a somewhat large number of bacteria in the soil was determined by the processing of post-harvest residues of peas, which was due to the biological characteristics of this legume culture.

At cultivating of winter wheat after spring barley using the stubble biodestructor the grain yield increased by $0.45 \mathrm{t} \mathrm{ha}^{-1}$, or $20.9 \%$, and after pea it increased by $0.67 \mathrm{t} \mathrm{ha}^{-1}$ or $18.8 \%$ compared to the treatment variant of stubble just with water.

\section{Authors' Contributions}

The author read and approved the final manuscript.

\section{Acknowledgements}

This research received no specific grant from any funding agency in the public, commercial, or not-forprofit sectors.

\section{Conflict of Interests}

The authors declare that there are no conflicts of interest related to this article.

\section{References}

Balayev AD, Pikovskaya OB (2016). Використання соломи у відновленні родючості грунтів [Use of straw in the restoration of soil fertility]. Kyiv, CP Commercial.

Gamajunova V. (2017). Sustainability of soil fertility in Southern Steppe of Ukraine, depending on fertilizers and irrigation. Soil science working for a living applications of soil science to present-day problems. Springer International Publishing Switzerland, pp 159-166.

Gamajunova VV, Kovalenko OA, Panfilova AV, Bolokhovskyi VV (2011). Вплив біодеструктора стерні на мікробіологічні показники грунту після ячменю ярого залежно від систем обробітку грунту та удобрення [Influence of the stubble biodestructor on microbiological parameters of soil after spring barley depending on tillage and fertilizer systems]. Proceedings of VNAU 7(47):7-11.

Gamajunova V, Panfilova A, Kovalenko O, Khonenko L, Baklanova T, Sydiakina O (2021). Better management of soil fertility in the Southern Steppe Zone of Ukraine. Better Management. Springer Nature Switzerland, pp 163171. https://doi.org/10.1007/978-3-030-68394-8_16

Hossain MZ, Fragstein P, Niemsdorff P, Heß J (2017). Effect of different organic wastes on soil properties and plant growth and yield: A review. Scientia Agriculturae Bohemica 48(4):224-237. https://doi.org/10.1515/sab-20170030

Hydbom S, Ernfors M, Birgander J, Hollander J, Jensen ES, Olsson PA (2017). Reduced tillage stimulated symbiotic fungi and microbial saprotrophs, but did not lead to a shift in the saprotrophic microorganism community structure. Applied Soil Ecology 119:104-114. https://doi.org/10.1016/j.apsoil.2017.05.032

Kõlli R (2018). Influence of land use change on fabric of humus cover (pro Humus form). Applied Soil Ecology 123:737739. https://doi.org/10.1016/j.apsoil.2017.06.022

Korsun S, Davydiuk G, Shkarivska L, Bolokhovskyi V, Bolokhovska V (2018). Changing the potential fertility of podzolized soils with the use of biological products. Agroecological Journal 1:50-56. 
Lupwayi NZ, Lafond GP, Ziadi N, Grant CA (2012). Soil microbial response to nitrogen fertilizer and tillage in barley and corn. Soil and Tillage Research 118:139-146. https://doi.org/10.1016/j.still.2011.11.006

Markovskaya OE (2018). Аинаміка чисельності мікроорганізмів у темно-каштановому грунті за різних систем основного обробітку та удобрення в сівозміні на зрошенні [Dynamics of microorganism in dark kastanozems in different systems of basic tillage and fertilizer in crop rotation on irrigation]. Agrology 1(3):294-299. https://doi.org/10.32819/2617-6106.2018.13009

McDonald JE, Rooks DJ, McCarthy AJ (2012). Methods for the isolation of cellulose degrading microorganisms. Methods in Enzymology 510:349-374. https://doi.org/10.1016/B978-0-12-415931-0.00019-7

Molina-Montenegro MA, Oses R, Atala C, Torres-Díaz C, Bolados G, León-Lobos P (2016). Nurse effect and soil microorganisms are key to improve the establishment of native plants in a semiarid community. Journal of Arid Environments 126:54-61. https://doi.org/10.1016/j.jaridenv.2015.10.016

Nilova NP, Novokhatsky ML, Bolokhovskaya VA, Rostotsky OV (2017). Біодеструктор стерні - ефективний засіб регулювання розкладання пожнивних решток [Biodestructor stubble is an effective means of management post-harvest residues]. Agricultural Machinery and Equipment 2(39):60-62.

Panfilova A, Gamayunova V, Smirnova I (2020). Influence of fertilizing with modern complex organic-mineral fertilizers to grain yield and quality of winter wheat in the southern steppe of Ukraine. Agraarteadus 31(2):196-201. https://doi.org/10.15159/jas.20.28

Panfilova A, Mohylnytska A (2019). The impact of nutrition optimization on crop yield of winter wheat varieties (Triticum aestivum L.) and modeling of regularities of its dependence on structure indicators. Agriculture \& Forestry 65(3):157-171. https://doi.org/10.17707/AgricultForest.65.3.13

Panfilova A, Mohylnytska A, Gamayunova V, Fedorchuk M, Drobitko A, Tyshchenko S (2020). Modeling the impact of weather and climatic conditions and nutrition variants on the yield of spring barley varieties (Hordeum vulgare L.). Agronomy Research 18(S2):1388-1403. https://doi.org/10.15159/AR.20.159

Salmonová H, Bunešová V (2017). Methods of studying diversity of bacterial communities: a review. Scientia Agriculturae Bohemica 48(3):154-165. https://doi.org/10.1515/sab-2017-0022

Sendetsky VM (2018). Ріст і розвиток рослин кукурудзи залежно віА застосування соломи і сидератів [Growth and development of corn plants depending on the use of straw and green manure crops]. Agrology 1(3):281-285. https://doi.org/10.32819/2617-6106.2018.13007

Sendetsky VM (2019). Урожайність та якісні показники зерна кукурудзи за сумісного застосування соломи та сидератів [Crop yields and quality indicators of corn under joint application of straw and green manure]. Taurian Scientific Bulletin 105:147-154.

Veremeenko SI, Semenko LO (2019). Сучасні проблеми деградації грунтів - трофічний аспект [Modern problems of soil degradation - trophic aspect]. Scientific Horizons 1(74):69-75. https://doi.org/10.332491/2663-21442019-74-1-69-75

Volkogon VV (2011). Біологічна меліорація грунтів. Традиційне і нове [Biological melioration of soils. Traditional and new]. Agricultural Microbiology 13:7-22.

Vovkodav VV (2001). Metodyka derzhavnoho sortovyprobuvannia silskohospodarskykh kultur (zernovi, krupiani ta zernobobovi) [The method of state variety testing of agricultural crops (grain, cereals, and leguminous plants)]. In: State Communication of Ukraine for Testing and Protection of Plant Varieties. ${ }^{\text {nd }}$ issue, Kyiv, pp 65

Wang Y, Li C, Tu C, Hoyt GD, DeForest JL, Hu S (2017). Long-term no-tillage and organic input management enhanced the diversity and stability of soil microbial community. Science of the Total Environment 609:341347.https://doi.org/10.1016/j.scitotenv.2017.07.053
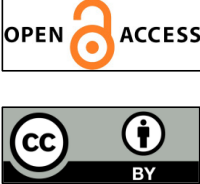

The journal offers free, immediate, and unrestricted access to peer-reviewed research and scholarly work. Users are allowed to read, download, copy, distribute, print, search, or link to the full texts of the articles, or use them for any other lawful purpose, without asking prior permission from the publisher or the author.

License - Articles published in Notulae Scientia Biologicae are Open-Access, distributed under the terms and conditions of the Creative Commons Attribution (CC BY 4.0) License.

(c) Articles by the authors; SHST, Cluj-Napoca, Romania. The journal allows the author(s) to hold the copyright/to retain publishing rights without restriction. 